$\underline{\text { Laporan Kasus }}$

\title{
Investigasi Forensik pada Kasus Kematian Dugaan Akibat Cedera Kepala
}

\section{Forensic Investigation on Alleged Death Case due to Head Injury}

\author{
Dedi Afandi ${ }^{1}$, Herkutanto ${ }^{2}$ \\ ${ }^{1}$ Laboratorium Kedokteran Forensik dan Medikolegal Fakultas Kedokteran Universitas Riau Pekanbaru \\ ${ }^{2}$ Laboratorium Kedokteran Forensik dan Medikolegal Fakultas Kedokteran Universitas Indonesia Jakarta
}

\begin{abstract}
ABSTRAK
Autopsi diperlukan dalam upaya menentukan penyebab kematian dan cara kematian. Autopsi seringkali tidak dapat dilakukan karena penolakan oleh keluarga. Laporan kasus ini menyajikan investigasi forensik pada kasus kematian yang diduga akibat cedera kepala pada korban yang telah dikremasi. Investigasi pada tempat kejadian meninggal, perhitungan indikator efek trauma pada kepala dan studi literatur dilakukan untuk membuktikan probabilitas kematian akibat cedera kepala dan probabilitas kemungkinan penyebab kematian pada korban. Dari metode tersebut didapatkan probabilitas terjadinya cedera otak traumatik ringan adalah 8,33\% dan probalitas kematian jantung mendadak $80,95 \%$. Kasus ini menunjukkan pentingnya memahami aspek medikolegal trauma, memahami biomekanika trauma dan melakukan investigasi forensik.
\end{abstract}

Kata Kunci: Biomekanika trauma, cedera kepala, cedera otak traumatik, investigasi forensik, kematian jantung mendadak

\begin{abstract}
An autopsy is needed in determining the cause of death and the manner of death. Family rejection is one of the reasons why autopsy can not be performed. This case report presents a forensic investigation on the alleged deaths due to a head injury on a cremated victim. Death scene investigation, the calculation of trauma effect indicators on the head, and literature study were conducted to prove the probability of death from head injury and probability of possible cause of death on the victim. From this method, the probability of mild Traumatic Brain Injury (mTBI) was 8,33\% and the probability of sudden cardiac death was $80,95 \%$. This case demonstrates the importance of understanding the medicolegal aspects of trauma, understanding trauma biomechanics, and conducting forensic investigations.
\end{abstract}

Keywords: Forensic investigation, head injury, sudden cardiac death, trauma biomechanics, traumatic brain injury

Korespondensi: Dedi Afandi. Laboratorium Kedokteran Forensik dan Medikolegal Fakultas Kedokteran Universitas Riau Pekanbaru, Jl. Diponegoro 1, Pekanbaru, Riau Tel. (0761) 839264 Email: dediafandi4n6@gmail.com

DOI: http://dx.doi.org/10.21776/ub.jkb.2018.030.01.12 


\section{PENDAHULUAN}

Cedera kepala merupakan permasalahan kesehatan global sebagai penyebab mortalitas dan morbiditas baik di negara maju maupun di negara yang sedang berkembang $(1,2)$. Pada tahun 2013, terjadi kurang lebih 2,8 juta kasus cedera kepala di Amerika Serikat dan sekitar 56.000 kematian berhubungan dengan cedera kepala (3). Laporan penelitian dari 29 negara menunjukkan bahwa angka kematian akibat cedera kepala berkisar antara 5,2 di Perancis sampai 80,73 di Afrika Selatan per 100.000 penduduk/tahun (1). Di Indonesia, proporsi angka ratarata nasional kejadian cedera kepala adalah 0,4\% dan meningkat sesuai kelompok umur (4).

Autopsi merupakan suatu tindakan medis yang bertujuan untuk menentukan sebab kematian dan bila memungkinkan cara kematian $(5,6)$. Pada kasus kematian diduga adanya tindakan kekerasan pada daerah kepala dan atau bagian tubuh lainnya merupakan indikasi dilakukan tindakan autopsi, akan tetapi pada kenyataannya sering terjadi penolakan dari keluarga yang terutama berhubungan dengan agama, biaya maupun budaya (5). Di Indonesia, autopsi masih merupakan baku emas dalam menentukan sebab kematian (7). Pada kasus ketika tindakan autopsi sudah tidak dapat dilakukan maka proses investigasi kematian dapat dilakukan melalui metode studi eksperimental, model matematika, dan studi literatur $(8,9)$. Biomekanika trauma merupakan salah satu metode yang dapat digunakan, namun penting digaris-bawahi bahwa hasil akhir analisis lebih kepada mekanisme terjadinya perlukaan dan probabilitas sebab kematian $(10,11)$. Metode ini telah berkembang secara pesat beberapa dekade terakhir dan dapat diterima oleh sebagian besar ahli forensik baik untuk kepentingan peradilan maupun non peradilan $(10,12,13)$.

Terdapat situasi ketika autopsi sudah tidak mungkin dilakukan lagi tetapi dibutuhkan pendapat tentang sebab kematian yang seakurat mungkin. Laporan kasus ini menyajikan investigasi kasus kematian yang diduga akibat cedera kepala namun tindakan autopsi sudah tidak dapat dilakukan karena jenazah sudah dikremasi. Sebuah perusahaan asuransi meminta dilakukan investigasi forensik atas pengajuan klaim asuransi kecelakaan dari korban yang diduga meninggal akibat cedera kepala. Pihak keluarga mengklaim bahwa cedera kepala tersebut terjadi karena peristiwa kecelakaan saat korban terjatuh di kamar mandi. Permintaan investigasi forensik untuk kepentingan asuransi (non peradilan) jarang dilakukan di Indonesia, dan belum ada publikasi daring tentang hal ini. Meskipun demikian, sebagai dokter tetap harus mengetahui karena tidak menutup kemungkinan adanya permintaan investigasi forensik untuk kasus dengan autopsi sudah tidak dapat dilakukan.

\section{KASUS}

Seorang laki-laki, 38 tahun, tinggi badan $160 \mathrm{~cm}$ dengan berat badan $65 \mathrm{~kg}$, ditemukan telah meninggal di kamar mandi oleh ibu korban kurang lebih pada jam 06.15 waktu setempat dan diperkirakan korban masuk ke kamar mandi pada jam 05.30. Posisi korban pada waktu ditemukan adalah dalam keadaan tertelungkup, dengan kedua kaki masih pada dudukan kloset jongkok. Dari keterangan keluarga didapatkan adanya memar pada dahi dan keluar sedikit darah dari kedua hidung korban, dan tidak ditemukan luka pada bagian tubuh lain. Riwayat pengobatan, 5 hari sebelum meninggal, korban mengeluh nyeri pada daerah dada dan telah berobat jalan di sebuah rumah sakit dengan diagnosis observasi nyeri dada. Tidak didapatkan data riwayat obat-obatan yang dikonsumsi oleh korban sebelum atau sesaat sebelum meninggal.

Tim selanjutnya mendatangi rumah korban untuk investigasi tempat kejadian meninggal dan membuat sketsa tempat kejadian. Dari investigasi tempat kejadian meninggal didapatkan data-data sebagai berikut (Gambar 1): Kamar mandi, tipe basah, keramik berlumut, panjang $177 \mathrm{~cm}$, lebar $172 \mathrm{~cm}$ dan tinggi $196 \mathrm{~cm}$. Pintu terletak di sebelah utara, terdapat 1 buah bak mandi ukuran $80 \mathrm{~cm} \mathrm{x}$ $67 \mathrm{~cm} \times 50 \mathrm{~cm}$ dan 1 buah kloset jongkok dengan ketinggian dari lantai dasar $24 \mathrm{~cm}$ yang terletak di sebelah selatan dari bak mandi atau bagian tenggara dari kamar mandi secara umum. Lebar lantai kloset $60 \mathrm{~cm}$ dan panjang lantai kloset $=105 \mathrm{~cm}$ (lebar kamar mandi dikurangi lebar bak mandi).

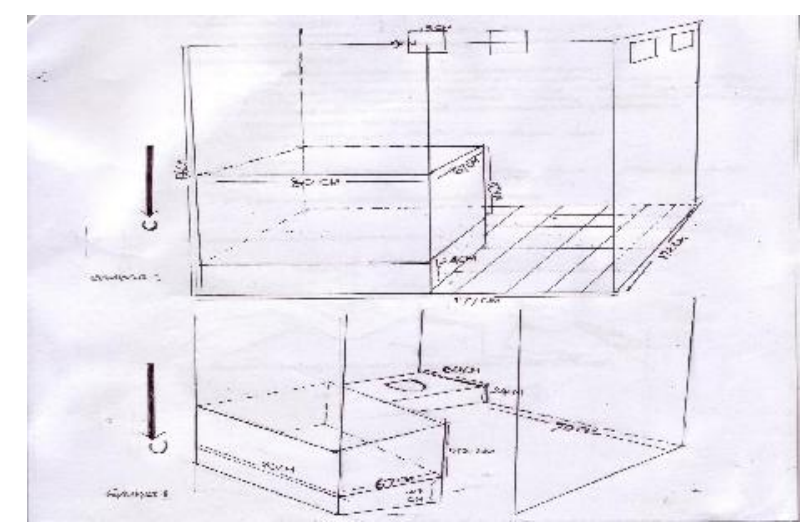

Gambar 1. Tempat kejadian korban meninggal

Keterangan: I. Menunjukkan tempat kejadian korban meninggal dilihat dari pintu masuk; II. Menunjukkan tempat kejadian korban meninggal dari sisi depan kamar mandi. ( $U=$ Utara)

Posisi korban saat ditemukan menghadap ke arah Barat, kaki masih pada pijakan kloset, kepala menghadap lantai, posisi tertelungkup. Jika dilihat dari arah utara maka ada dua daerah dengan ketinggian yang berbeda yaitu terdapat daerah dengan ketinggian $24 \mathrm{~cm}$ dari lantai sepanjang $60 \mathrm{~cm}$ dan terdapat daerah setinggi lantai dasar sepanjang $117 \mathrm{~cm}$ (panjang kamar mandi dikurangi daerah lantai kloset).

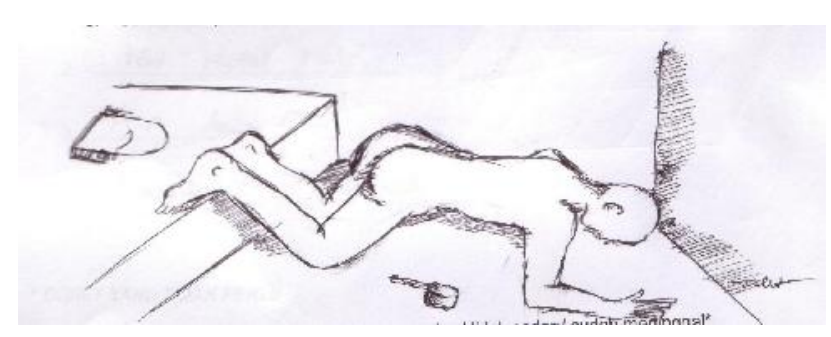

Gambar 2. Posisi korban sewaktu ditemukan.

Dari hasil kunjungan ke tempat kejadian meninggal, keterangan dari pihak keluarga dan melihat foto korban tampak kepala-kaki, serta fakta-fakta di lapangan, maka tim 
forensik menyimpulkan bahwa kemungkinan posisi korban pada saat jatuh adalah sedang jongkok pada pijakan kloset. Simpulan ini didasarkan dari analisis dan fakta berikut. Korban belum sempat membersihkan anusnya. Jika korban berdiri pada pijakan kloset maka tinggi korban secara keseluruhan terhadap lantai kamar mandi adalah $160 \mathrm{~cm}+24 \mathrm{~cm}=184 \mathrm{~cm}$. Apabila kloset berada pada pertengahan lantai kloset $(60: 2)$ atau $30 \mathrm{~cm}$, maka korban akan jatuh pada jarak $130 \mathrm{~cm}$ ke arah depan di lantai dasar (tinggi badan dikurangi pertengahan kloset). Data menunjukkan bahwa panjang lantai dasar yang bukan bagian dari lantai kloset adalah $117 \mathrm{~cm}$, maka besar kemungkinan kepala korban akan membentur tembok sebelah barat terlebih dahulu. Karena terdapat perbedaan jarak sepanjang $13 \mathrm{~cm}(130 \mathrm{~cm}-117 \mathrm{~cm})$ maka korban setelah membentur tembok barat, posisi yang paling mungkin adalah wajah menghadap tembok atau korban mendapat gaya balik ke belakang. Melihat posisi wajah korban yang menyentuh lantai kamar mandi maka kemungkinan besar posisi korban pada saat jatuh adalah pada posisi jongkok atau defekasi. Dasar simpulan yang lain adalah pada posisi jongkok, maka ketinggian korban (dari lantai kamar mandi) adalah $24 \mathrm{~cm}$ ditambah dengan panjang kepala tungging. Melihat perbandingan foto lengkap korban dapat diperkirakan bahwa panjang kepala tungging korban adalah sepanjang $80 \mathrm{~cm}$. Berdasarkan data tersebut ketinggian korban pada saat jatuh adalah $80 \mathrm{~cm}+24 \mathrm{~cm}=104 \mathrm{~cm}$. Bila pertengahan pijakan kloset adalah $30 \mathrm{~cm}$, maka jarak korban akan jatuh ke arah depan minimal pada jarak $50 \mathrm{~cm}$ dengan kaki masih pada pijakan kloset.

Terdapat dua tujuan utama dari investigasi forensik yaitu untuk mendapatkan probabilitas cedara kepala sebagai penyebab kematian korban, dan mendapatkan probabilitas sebab kematian akibat selain cedara kepala. Untuk membuktikan apakah cedera kepala yang didapat oleh korban dapat menimbulkan kematian, maka selanjutnya dilakukan perhitungan-perhitungan efek trauma terhadap kepala.

\section{Energi Impak pada Saat Korban Jatuh}

Menurut Hukum Newton's III, besarnya gaya aksi = gaya reaksi. Bila kepala mendekati benda yang diam maka besarnya energi impak yang diterima kepala adalah sebanding dengan energi sewaktu kepala membentur lantai. $\Sigma F$ aksi $=-\Sigma$ F reaksi.

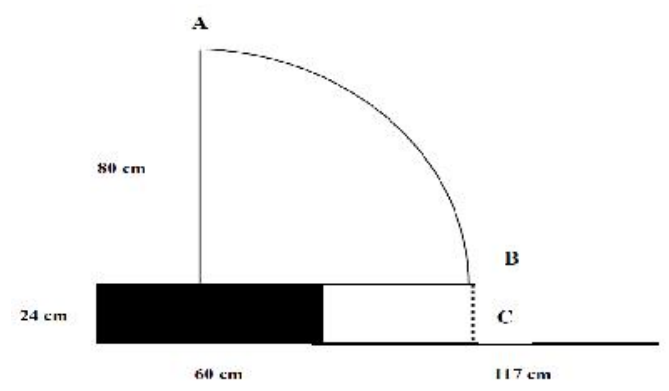

Gambar 3. Ilustrasi pergerakan kepala korban

Keterangan: terdapat dua kondisi pergerakan yang terjadi pada korban yaitu: posisi A ke B korban mengalami gerak melingkar beraturan (rotational motion) dan posisi B ke C korban mengalami gerak jatuh bebas (linear motion). Nilai-nilai yang diketahui: Sudut $A-B(\theta)=90^{\circ} ; \mathrm{r}$ (jari-jari) $=80 \mathrm{~cm}=0,8 \mathrm{~m} ; \mathrm{h}$ (tinggi lantai kloset) $=24 \mathrm{~cm}=0,24 \mathrm{~m}$; Kecepatan awal di A (V0) $=0 \mathrm{~m} / \mathrm{s}$; Tinggi Badan (TB) $=160 \mathrm{~cm}=1,6 \mathrm{~m}$; Berat Badan BB) $=65 \mathrm{~kg}$.
Massa kepala dan momen inersia dari kepala (14) dihitung dengan rumus $1,296+0,01710(B B)+$ 0,01430 (TB). Berdasarkan nilai yang diketahui (Gambar3) didapatkan massa kepala adalah sebesar 4,7kg. Rasio Center of Gravity (COG) pada kepala adalah 8,357-0,0025 (BB)+0,023 (TB). Dengan memasukkan nilai pada data didapatkan rasio COG adalah $12,2 \% \mathrm{E}$. Dari data tempat kejadian diketahui bahwa korban jatuh ke depan dan terdapat memar pada dahi sehingga momen inersia kepala (I) adalah pada $+x$-axis, yaitu sebesar $241,2 \times 12,2 \%$ $=29,4 \mathrm{~kg} \cdot \mathrm{cm}^{2}$ atau setara dengan $0,003 \mathrm{~kg} \cdot \mathrm{m}^{2}$ (N.m.s ${ }^{2}$ )

Gerak Kinetik Kepala dari Posisi Jongkok Sampai Menyentuh Lantai

Jika kita ilustrasikan gerak yang terjadi pada kepala adalah gerak melingkar beraturan (Rotational motion) dari A ke B dan gerak jatuh bebas dari B ke $C$. Kepala bisa diasumsikan sebuah benda pejal yang melakukan gerak rotasi murni dengan sumbu tetap (sumbu z) yang tegak lurus bidang $x y$. Setiap partikel mengalami gerak rotasi terhadap titik 0 . (Gambar 4.a)

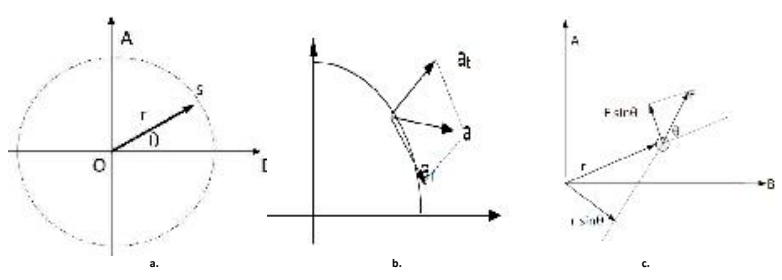

Gambar 4. Ilustrasi pergerakan melingkar beraturan kepala korban

Untuk mendapatkan besarnya energi impak yang mengenai kepala pada saat mengenai lantai kamar mandi, maka dilakukan perhitungan-perhitungan (Tabel 1). (Lampiran 1)

\section{Perhitungan Biomekanika Trauma pada Kepala}

Untuk dapat mendapatkan simpulan probabilitas kematian korban akibat cedera kepala dilakukan perhitungan indikator-indikator biomekanika trauma pada kepala yang berhubungan dengan terjadinya mild Traumatic Brain Injury (mTBI.) Berdasarkan perhitunganperhitungan sesuai dengan rumus, parameter yang digunakan, hasil perhitungan berdasarkan mekanisme perlukaan pada korbaan, selanjutnya dibuat simpulan dengan cara membandingkan hasil perhitungan pada korban dengan parameter yang telah ditetapkan berdasarkan literatur. Perhitungan pada Tabel 2 menunjukkan bahwa risiko $\mathrm{mTBI}$ pada korban adalah kecil dengan menggunakan beberapa indikator.

Perhitungan probabiltas terjadinya mTBI pada korban berdasarkan 8 indikator yang digunakan Tabel 2 dan Lampiran 2 yang kemudian dilakukan penghitungan skor probabilitas (Tabel 3). Sistem pemberian skor: $0=$ probabilitas $0-1 \% ; 1=$ probabilitas 1,1-5\%; 2 = probabilitas $5,1-50 \%$ dan $3=$ probabilitas $50,1-100 \%$. Dengan skor maksimal yang dapat diperoleh 24 , total skor pada korban $=2$, maka kuantifikasi probabilitas terjadinya cedera kepala pada korban adalah $8,33 \%$. 
Tabel 3. Ikhtisar probabilitas dan skor dari variabel indikator biomekanika trauma

\begin{tabular}{lrc}
\hline \multicolumn{1}{c}{ Variabel } & Probabilitas & Skor \\
\hline Maximum linear acceleration & $0,12 \%$ & 1 \\
Maximum linear acceleration & $0,02 \%$ & 0 \\
dihubungkan dengan waktu & & \\
Severity Index & $0,14 \%$ & 0 \\
The Head Injury Criterion (HIC) & $2,9 \%$ & 1 \\
Percepatan linear dan sudut GAMBIT & $0,0002 \%$ & 0 \\
Rata-rata percepatan dengan lamanya & $<1 \%$ & 0 \\
waktu & & \\
Head Injury Power (HIP) & $0,02 \%$ & 0 \\
TRISS (Trauma Injury Severity Score) & $0,3 \%$ & 0 \\
\hline
\end{tabular}

Untuk menjawab tujuan investigasi nomor dua, yaitu mendapatkan probabilitas sebab kematian akibat selain cedara kepala, dilakukan analisis berdasarkan riwayat penyakit sebelumnya sebagai faktor individu korban. Informasi yang digunakan adalah riwayat pengobatan yang dilakukan oleh korban 5 hari sebelum meninggal korban. Korban mengeluh batuk-batuk dan nyeri dada, serta telah mendapatkan pengobatan rawat jalan dengan diagnosis observasi nyeri dada. Berdasarkan studi literatur, dilakukan perhitungan probabilitas kematian akibat kematian jantung mendadak dengan metode skoring pada 7 indikator yaitu: insiden, riwayat nyeri dada, penyakit kardiovaskular, jenis kelamin, usia, waktu kejadian, dan aktifitas maka didapatkan skor 17 dari 21 skor maksimal. Kuantifikasi probabilitas kematian jantung mendadak pada korban ini adalah 80,95\%.

Kesimpulan akhir dari hasil investigasi forensik adalah korban ditemukan meninggal di kamar mandi yang oleh sebab apapun peristiwa jatuhnya (terpeleset atau "sebab lain") dengan probabilitas cedera kepala adalah sebesar $8,33 \%$. Menurut data dan hasil perhitungan, tidak satupun data yang mendukung untuk terjadinya cedera otak traumatik yang dapat menyebabkan kematian. Probabilitas sebab kematian akibat "sebab lain" dalam hal ini kematian jantung mendadak adalah sebesar $80,95 \%$. Menurut literatur, penyakit jantung merupakan penyumbang kematian mendadak yang terbanyak dibandingkan dengan penyakit lainnya.

Waktu yang dibutuhkan untuk menyelesaikan investigasi kematian pada kasus ini adalah 3 bulan. Setelah laporan ini diberikan kepada pihak perusahaan asuransi yang meminta dan dilakukan presentasi di depan ahli waris korban, hasil investigasi ini dapat diterima oleh kedua belah pihak. Berdasarkan laporan ini, pihak asuransi membayarkan uang pertanggungan kepada ahli waris korban sebesar $8,33 \%$ dari seluruh uang pertanggungan yang tercantum dalam klausul asuransi kecelakaan.

\section{DISKUSI}

Aspek medikolegal pada kasus cedera kepala meliputi: 1 . Apakah cedera tersebut dapat menyebabkan kematian? 2. Bagaimana mekanisme terjadinya trauma? 3. Apakah kasus ini suatu kasus pembunuhan, bunuh diri atau kecelakaan? 4. Apakah ada faktor lain/individu yang berkontribusi? Untuk menjawab pertanyaan-pertanyaan tersebut diperlukan pemeriksaan autopsi dan investigasi forensik (6). Efek trauma terhadap kepala dapat berupa luka pada kulit kepala, patah tulang, komosio, kontusio, perdarahan epidural, perdarahan sub dural, perdarahan sub arachnoid sampai dengan kerusakan intra kranial $(17,18)$. Efek yang timbul pada kepala sebanding dengan besar nya energi impak yang mengenai kepala, pergerakan kepala, akselerasi linier dan melingkar dari kepala serta tekanan dan peregangan (18). Pada laporan kasus ini digunakan 2 metode yaitu model matematika dan studi literatur $(8,9)$. Metode yang paling baik dalam investigasi forensik adalah eksperimental. Dari beberapa literatur, eksperimental dilakukan dengan cara menggunakan Finite Element Model dan model tersebut disimulasikan beberapa mekanisme trauma berdasarkan data-data yang didapat dari tempat korban meninggal, selain itu juga dapat digunakan aplikasi perangkat lunak Mathematic Dynamic Model (MADYMO $\left.{ }^{\circledR}\right)(8,9,19,20)$. Meskipun demikian, untuk melakukan metode eksperimen tersebut membutuhkan alat-alat yang canggih dan aplikasi perangkat lunak MADYMO ${ }^{\circledR}$ yang relatif sangat mahal.

Luka yang terjadi pada kepala dapat berupa lecet, memar, dan laserasi. Kepala dilindungi oleh lapisan scalp dan rambut. Kulit kepala yang utuh dan adanya rambut akan mengurangi terjadi efek terhadap kepala secara keseluruhan, selain faktor kekuatan impak juga dipengaruhi lamanya waktu (durasi) benturan terhadap kepala (21). Pada laporan kasus ini ditemukan memar pada dahi korban berdasarkan keterangan dari keluarga korban. Retakan kecil pada tulang kepala dapat terjadi bila gaya yang bekerja pada kepala sebesar minimal $73 \mathrm{~N}$ (18), akan tetapi hal ini juga dipengaruhi oleh luas area yang mengenai kepala, ketebalan tulang kepala, kulit kepala dan rambut, benturan langsung dan faktor lainnya. Penelitian menunjukkan bahwa terdapat variasi gaya yang cukup lebar untuk dapat menimbulkan fraktur tulang kepala, berkisar antara $73 \mathrm{~N}$ sampai dengan $1314 \mathrm{~N}(17,18)$.

Pada cedera kepala, tulang tengkorak yang tidak terlindungi oleh kulit hanya mampu menahan benturan sampai 40pound/inch ${ }^{2}$, tetapi bila terlindung oleh kulit maka dapat menahan sampai 425.900pound/inch (18). Defleksi pada tulang kepala dapat terjadi bila kecepatan kepala antara 4,9-7,7m/s dan dibutuhkan gaya yang besar untuk menyebabkan terjadinya defleksi. Defleksi sebesar 10-19mm membutuhkan gaya sebanyak 5,5-9,9kN (19). Fraktur pada tulang kepala juga dipengaruhi oleh luas daerah kontak. Jika korban jatuh wajah terlebih dahulu, kita dapat asumsikan lebar wajah rata-rata adalah lebar (Bitragion breadth) dikalikan tinggi wajah (menton to top the head) yaitu $13,9 \times 22,3=309,97 \mathrm{~cm}^{2}$, sebagai perbandingan kepala yang dijatuhkan dari ketinggian $102 \mathrm{~cm}$ dengan luas daerah kontak $52 \mathrm{~cm}^{2}$ membutuhkan gaya sebesar 5,8-17kN (rata-rata $12,4 \mathrm{kN}$ ) (19). Jika dilihat dari kecepatan rata-rata, dan gaya yang bekerja pada korban, maka sangat kecil kemungkinan terjadinya fraktur pada tulang kepala.

Konkusio terjadi kira-kira 60-100 G-force dan batas minimal untuk terjadinya perubahan pada permukaan otak adalah sebesar $2 \times 10^{4} \mathrm{rad} / \mathrm{s}^{2}$, atau $0,4 \times 10^{4} \mathrm{rad} / \mathrm{s}^{2}$, atau $0,2 \times 10^{4} \mathrm{rad} / \mathrm{s}^{2}(9,19,20)$. Berdasarkan data-data yang ada dapat disimpulkan bahwa pada korban ini tidak terjadi komosio atau kontusio terhadap jaringan otaknya. Tekanan yang bekerja sehingga mampu menghasilkan kontusio otak dibutuhkan tekanan sebesar $>30 \mathrm{kPa}$. Jika dianggap luas area kontak adalah $309,97 \mathrm{~cm}^{2}$ atau $0,03 \mathrm{~m}^{2}$ dan gaya yang bekerja adalah $9,42 \mathrm{~N}$ maka tekanan yang diperoleh adalah $0,3 \mathrm{kPa}$. Ini menunjukkan bahwa tekanan pada kepala korban belum mampu membuat kontusio otak. Demikian juga dengan komosio karena dibutuhkan 
tekanan sebesar $15-20 \mathrm{kPa}$ (19). Dengan percepatan anguler korban $\left(9,8 \mathrm{rad} / \mathrm{s}^{2}\right)$ maka tidak mungkin terjadi perdarahan sub dural pada korban ini, karena dibutuhkan percepatan anguler minimal sebesar $1,5 \times 10^{5} \mathrm{rad} / \mathrm{s}^{2}$ dengan waktu $4 \mathrm{~ms}(9,19,20)$. Cedera tertutup kepala memungkinkan terjadinya contrecoup, lesi coup bisa dikatakan hampir tidak ada atau negatif. Data penelitian menunjukkan bahwa daerah kontak pada frontal atau dahi hanya akan menyebabkan lesi coup saja tanpa lesi contrecoup. Lesi coup pun hanya mungkin bila jatuh dari ketinggian yang melebihi tinggi badan. Resiko trauma sebanding dengan energi yang didapat dari benda yang mengenai kepala (9). Berdasarkan investigasi kematian dengan kemungkinan terjadinya mTBI sebesar $8,33 \%$ dan studi literatur maka cedera kepala pada korban tidak dapat menyebabkan kematian. Hal ini sesuai dengan penelitian di Bandung (21) yang melaporkan angka keluaran klinis baik pada mTBI adalah sebesar 94,7\%. Cara kematian pada korban ini bukanlah merupakan suatu pembunuhan, bunuh diri atau kecelakaan, hal ini berdasarkan luka tunggal yang ditemukan pada kepala, dan hasil olah tempat kejadian meninggal yang teratur dan tidak ditemukan kerusakan pada benda-benda yang terdapat pad tempat kejadian perkara.

Nyeri dada adalah salah satu gejala yang sering ditemukan dan berhubungan dengan tanda kelainan jantung. Penelitian di Pakistan (22) menunjukkan bahwa 93,1\% penderita serangan jantung (infark miokard) mengalami gejala nyeri dada, sementara penelitian lain melaporkan bahwa $87,6 \%$ penderita serangan jantung mengeluhkan nyeri dada(23).

Kematian jantung mendadak dilaporkan lebih tinggi pada laki-laki dibandingkan perempuan, beberapa penelitian melaporkan bahwa insiden kematian jantung mendadak pada laki-laki sebesar 44,6/100.000/tahun dan pada perempuan 39/100.000/tahun (24). Sementara itu penelitian yang dilakukan di India dengan metode autopsi, $78 \%$ korban kematian jantung mendadak adalah laki-laki (24). Rasio kematian jantung mendadak laki-laki terhadap perempuan adalah 3:1 (24). Angka kejadian kematian jantung mendadak meningkat sesuai umur baik pada laki maupun perempuan (24-27). Usia terbanyak untuk menderita serangan jantung adalah lebih dari 65 tahun (22,24-27), penelitian di Australia melaporkan bahwa $31 \%$ penderita jantung iskemik berusia di bawah 60 tahun (25). Beberapa penelitian menunjukkan bahwa

\section{DAFTAR PUSTAKA}

1. Li M, Zhao Z, Yu G, and Zhang J. Epidemiology of Traumatic Brain Injury over the World: A Systematic Review. Austin Neurology \& Neurosciences. 2016; 1(2): 1-14.

2. Majdan M, Plancikova D, Brazinova A, et al. Epidemiology of Traumatic Brain Injuries in Europe: A Cross-Sectional Analysis. The Lancet Public Health. 2016; 1(2): e76-e83.

3. Taylor C, Bell J, Breiding J, and Xu L. Traumatic Brain Injury-Related Emergency Department Visits, Hospitalizations, and Deaths-United States, 2007 and 2013. Morbidity and Mortality Weekly Report Surveillance Summaries. 2017; 66(9): 1-16.

4. Badan Penelitian dan Pengembangan Kesehatan. kebiasaan merokok meningkatkan resiko terjadinya serangan jantung. Penelitian Farmingham menunjukkan bahwa insiden kematian akan meningkat sebesar 2,5 kali bila merokok lebih dari 20 batang per hari. Keterangan keluarga menyatakan bahwa pasien merokok 3-4 batang per hari. Kebiasaan merokok menyumbang angka 25\% menimbulkan resiko kematian pada laki-laki berusia kurang dari 65 tahun (24-27).

Studi literatur menunjukkan bahwa waktu puncak terjadinya serangan jantung adalah jam 06.01-12.00 $(28,29)$. Dari keterangan keluarga klien masuk kamar mandi jam 05.30 dan ditemukan pada jam 06.15. Jika korban mendapat serangan jantung pada jam 05.30-06.00 maka kemungkinan korban mendapat serangan jantung adalah 22\% dan jika korban meninggal jam 06.01-06.15 maka kemungkinan korban mendapat serangan jantung adalah 32\% (28). Menurut literatur aktifitas yang dilakukan oleh pasien dapat mencetuskan terjadinya serangan jantung. Mengedan saat defekasi merupakan salah satu pencetus terjadinya fibrilasi ventrikel pada jantung yang sudah mengalami kelainan sebelumnya seperti penyempitan koroner atau hipertrofi ventrikel kiri $(30,31)$. Pada kasus ini sangat mungkin terjadi mengingat korban meninggal tidak berselang lama setelah defekasi dan korban belum sempat membersihkan lubang anusnya. Secara statistik, fibrilasi ventrikel adalah mekanisme kematian terbanyak dari kematian jantung mendadak. Angka situational syncope seperti defekasi berkisar antara $1-8 \%$ (rata-rata 5\%)(32).

Sesuai dengan tuntutan masyarakat terhadap ilmu kedokteran forensik, maka sangat penting bagi spesialis kedokteran untuk memahami aspek medikolegal trauma, memahami biomekanika trauma dan dapat melakukan investigasi forensik dengan baik. Peningkatan kompetensi di bidang biomekanika trauma penting dilakukan terutama dalam menghadapi dan menangani kasus di mana tindakan autopsi sudah tidak dapat dilakukan.

Autopsi tetap menjadi cara untuk menentukan penyebab kematian yang paling akurat. Dalam keadaan tertentu ketika autopsi tidak mungkin dilakukan masih dapat dilakukan penyimpulan sebab kematian dengan derajat akurasi dibawah tindakan autopsi. Penyimpulan sebab kematian dengan derajat akurasi dibawah tindakan autopsi dapat digunakan untuk kasus-kasus yang bersifat perdata.

Riset Kesehatan Dasar (RISKESDAS) 2013. Jakarta: Kementrian Kesehatan RI; 2013; Hal. 101-109.

5. Afandi D. Profile of Medicolegal Autopsies in Pekanbaru, Indonesia 2007-2011. The Malaysian Journal of Pathology. 2012; 34(2): 123-126.

6. Stankov A, Cakar L, Bitoljanu N, BelakaposkaSrpanova V, Bujaroska M, and Cakar Z. Forensik Aspect of Cerebral Contusions. Macedonian Medical Review. 2014; 68(2): 101-103.

7. Afandi D. Otopsi Virtual. Majalah Kedokteran Indonesia. 2009; 59(7): 327-332.

8. Anderson R and McLean J. Biomechanics of Closed Head Injury. In: Reilly P and Bullock R (Eds). Head Injury. London: Chapman \& Hall; 1997; Hal. 26-40.

9. Hayes WC, Erickson MS, and Power ED. Forensik 
Injury Biomechanics. The Annual Review Biomedical Engineering. 2007; 9(1): 55-86.

10. Freeman MD and Kohles SS. Applications and Limitations of Forensic Biomechanics: A Bayesian Perspective. Journal of Forensic and Legal Medicine. 2010; 17(2): 67-77.

11. Motherway J, Doorly MC, Curtis M, and Gilchrist MD. Head Impact Biomechanics Simulations: A Forensic Tool for Reconstructing Head Injury? Legal Medicine. 2009; 11(1): s220-s222.

12. Tong DC, Winter TJ, Jin J, Bennett AC, and Waddell JN. Quantification of Subconcussive Impact Forces to the Head Using a Forensic Model. Journal of Clinical Neuroscience. 2015; 22(4): 747-751.

13. Ruwanpura R. The Mechanics of Injury Production and Wounding Forces in Judicial Context. International Journal of Medical Toxicology and Forensic Medicine. 2015; 5(2): 78-80.

14. Zatsiorsky VM and Seluyanov VN. The Mass and Inertia Characteristics of the Main Segments on the Human Body. Journal of Biomechanic. 1983; 5(3B): 1152-1159.

15. Young T. Predicting Mild Traumatic Brain Injury with Injury Risk Functions. Proceedings of the Brain Injuries \& Biomechanics Symposium. Washington DC, April 4, 2013; pp. 1-9

16. Purwati WD, Wardhani V, Mahameru G, dan Istiadjid M. Penggunaan Suksinilkolin Setelah Rapid Sequence Intubation Tidak Meningkatkan Kadar Kalium Plasma Pasien dengan Cedera Kepala Berat. Jurnal Kedokteran Brawijaya. 2009; 25(2): 71-76.

17. Zappala G, de Schotten MT, and Eslinger PJ. Traumatic Brain Injury and the Frontal Lobes: What Can We Gain with Diffusion Tensor Imaging? Cortex. 2012; 48(2): 156-165.

18. Saukko $\mathrm{P}$ and Knight B. KNIGHT'S Forensik Pathology. 4th edition. New York: CRC Press; 2016; pp. 167-214.

19. Horgan T. A Finite Element Model of the Human Head for Use in the Study of Pedestrian Accidents. [Thesis]. University College Dublin, Irlandia. 2005.

20. Hernandez F, Wu LC, Yip MC, et al. Six Degree-ofFreedom Measurements of Human Mild Traumatic Brain Injury. Annals of Biomedical Engineering. 2015; 43(8): 1918-1934.
21. Zamzami NM, Fuadi I, dan Nawawi AM. Angka Kejadian dan Outcome Cedera Otak di RS Hasan Sadikin Bandung Tahun 2008-2010. Jurnal Neuroanestesia Indonesia. 2013; 2(2): 89-95.

22. Malik MA, Khan SA, Safdar S, and Taseer IU. Chest Pain as A Presenting Complaint in Patients with Acute Myocardial Infarction (AMI). Pakistan Journal of Medical Science. 2013; 29(2): 565-568.

23. Vahdati SS, Rajavpour ZV, Paknezhad SP, et al. CostEffectiveness of Cardiac Biomarkers as Screening Test in Acute Chest Pain. Journal of Cardiovascular and Thoracic Research. 2014; 6(1): 29-33.

24. Srivatsa UN, Swaminathan K, Munavarah KSA, Amsterdam E, and Shantaraman K. Sudden Cardiac Death in South India: Incidence, Risk Factors and Pathology. Indian Pacing and Electrophysiology Journal. 2016; 16(4): 121-125.

25. Vedanthan R, Fuster V, and Fischer A. Sudden Cardiac Death in Low- and Middle-Income Countries. Global Heart. 2012; 7(4):353-360.

26. Hua W, Zhang LF, Wu YF, et al. Incidence of Sudden Cardiac Death in China. Analysis of 4 Regional Populations. Journal of the American College Cardiology. 2009; 54(12): 1110-1118.

27. Kong MH, Fonarow GC, Peterson ED, et al. Systematic Review of the Incidence of Sudden Cardiac Death in the United States. Journal of the American College Cardiology. 2011; 57(7): 794-801.

28. Nakashima $H$, Mashimo $Y$, Kurobe $M$, Muto $S$, Furudono S, and Maemura K. Impact of Morning Onset on the Incidence of Recurrent Acute Coronary Syndrome and Progression of Coronary Atherosclerosis in Acute Myocardial Infarction. Circulation Journal. 2017; 81(3): 361-367.

29. Inamasu J and Miyatake S. Cardiac Arrest in the Toilet: Clinical Characteristics and Resuscitation Profiles. Environmental Health and Preventive Medicine. 2013; 18(2): 130-135.

30. Takeda N and Maemura K. Circadian Clock and Cardiovascular Disease. Journal of Cardiology. 2011; 57(3); 249-256.

31. da Silva RMFL. Syncope: Epidemiology, Etiology, and Prognosis. Frontier in Physiology. 2014: 5: 471-474.

32. Gauer RL. Evaluation of Syncope. American Family Physician. 2011; 84(6): 640-650. 


\section{Lampiran 1}

Tabel 1. Perhitungan gerakan kinetik kepala, rumus, hasil perhitungan, dan makna

\begin{tabular}{|c|c|c|c|}
\hline Variabel & Rumus & Hasil Perhitungan & Makna \\
\hline Jarak A-B (busur s) (Gambar 4.a) & $s=r \cdot \theta$ & $\begin{array}{l}0,8 \times\left(90^{\circ} / 57,3^{\circ}\right) \\
=1,26 \mathrm{~m}\end{array}$ & $\begin{array}{l}\text { Busur s adalah jarak yang ditempuh oleh kepala mulai } \\
\text { dari posisi korban jongkok (A) sampai posisi kepala } \\
\text { setinggi tinggi kloset dari lantai (B). }\end{array}$ \\
\hline \multicolumn{4}{|l|}{$\begin{array}{l}\text { Percepatan kepala pada A-B } \\
\text { (Gambar 4.b) }\end{array}$} \\
\hline Percepatan sudut $(\alpha)$ pada A-B & g. $\operatorname{Sin} \theta$ & $9,8 \times 1=9,8 \mathrm{rad} / \mathrm{s}^{2}$ & $\begin{array}{l}\text { Kepala mengalami percepatan sebesar } 9,8 \mathrm{rad} / \mathrm{s}^{2} \text {, hasil ini } \\
\text { diperlukan untuk menghitung kecepatan linier kepala. }\end{array}$ \\
\hline Kecepatan linier (v) pada A-B & $\sqrt{ } \alpha . r$ & $\begin{array}{l}\sqrt{ } 9,8 \cdot 0,8=\sqrt{ } 7,8=2,8 \mathrm{~m} / \mathrm{s} \\
\text { atau setara dengan } 9,2 \mathrm{ft} / \mathrm{s}\end{array}$ & Kecepatan kepala saat jatuh dari posisi A ke posisi B. \\
\hline Kecepatan sudut $(\omega)$ pada A-B & $v / r$ & $2,8 / 0,8=3,5 \mathrm{rad} / \mathrm{s}$ & Kecepatan kepala saat menempuh busur s (dari A-B). \\
\hline Percepatan tangensial (at) & $\alpha . r$ & $9,8 \times 0,8=7,84 \mathrm{rad} / \mathrm{s}^{2}$ & Percepatan linier kepala pada gerak busur s. \\
\hline Percepatan radial $\left(a_{r}\right)$ & $\omega^{2} \cdot r$ & $(3,5)^{2} \times 0,8=9,8 \mathrm{rad} / \mathrm{s}^{2}$ & $\begin{array}{l}\text { percepatan yang dialami kepala yang bergerak melingkar } \\
\text { beraturan dan arah percepatan selalu menuju pusat } \\
\text { lingkaran. }\end{array}$ \\
\hline Percepatan total kepala & $\mathrm{a}=\mathrm{vat}^{2}+\mathrm{ar}^{2}$ & $\begin{array}{l}\sqrt{ }(7,84)^{2}+(9,8)^{2}=\sqrt{ } 61,5+ \\
96,04=\sqrt{ } 157,54= \\
12,6 \mathrm{rad} / \mathrm{s}^{2} \text { atau setara }\end{array}$ & $\begin{array}{l}\text { Percepatan total yang dialami oleh kepala saat melewati } \\
\text { busur s. Hasil perhitungan ini diperlukan pada saat } \\
\text { menghitung sudut GAMBIT. }\end{array}$ \\
\hline Waktu yang diperlukan $(\mathrm{t})$ dari A-B & $s / v$ & $\begin{array}{l}\text { dengan } 1,3 G \\
1,26 / 2,8=0,45 s\end{array}$ & $\begin{array}{l}\text { Waktu yang dibutuhkan oleh kepala untuk melewati } \\
\text { busur s (jarak A-B). }\end{array}$ \\
\hline Gaya torsi ( $\tau$ ) (Gambar 4.c) & I. $\alpha$ & $\begin{array}{l}0,003 \times 9,8=0,03 \mathrm{~N} \text { atau } \\
\text { setara dengan } 0,007 \mathrm{lbs}\end{array}$ & $\begin{array}{l}\text { kemampuan sebuah gaya untuk membuat kepala } \\
\text { melakukan gerak rotasi. }\end{array}$ \\
\hline Momentum sudut (L) & I. $\omega$ & $0,003 \times 3,5=0,001$ & $\begin{array}{l}\text { Momentum linier dari kepala yang diarahkan ke titik } 0 \\
\text { (pusat) }\end{array}$ \\
\hline Energi yang bekerja pada A-B & $1 / 2 \cdot 1 . \omega^{2}$ & $\begin{array}{l}1 / 2 \times 0,003 \times(3,5)^{2}=0,02 \\
\text { Joule }\end{array}$ & Energi yangbekerja pada kepala saat menempuh busur s. \\
\hline Kekuatan Power $(P)$ & $\tau . \omega$ & $0,03 \times 3,5=0,1 \mathrm{~W}$ & $\begin{array}{l}\text { Daya atau kekuatan yang diterima oleh kepala per satuan } \\
\text { waktu saat melewati busur s. }\end{array}$ \\
\hline $\begin{array}{l}\text { Gerak dari B ke C } \\
\text { Data dasar: } h=0,24 \mathrm{~m} ; \quad a b= \\
9,8 \mathrm{rad} / \mathrm{s}^{2} ; \mathrm{vb}=2,8 \mathrm{~m} / \mathrm{s} ; \quad \dot{b}= \\
3,5 \mathrm{rad} / \mathrm{s} ; \mathrm{Tb}=0,56 \mathrm{~s} \text { dan } \mathrm{Fb}=0,03 \mathrm{~N} \text {, } \\
\text { sehingga kecepatan di } \mathrm{C} \text { adalah } \\
\text { kecepatan di B (Vb) ditambah } \\
\text { dengan kecepatan jatuh bebas Vbc. }\end{array}$ & & & \\
\hline $\begin{array}{l}\text { Perhitungan kepala mencapai } \\
\text { lantai } \\
\text { Kecepatan (Vc) }\end{array}$ & $V c^{2}=V b^{2}+2 g h$ & $\begin{array}{l}\mathrm{Vc}=3,54 \mathrm{~m} / \mathrm{s} \text { atau setara } \\
\text { dengan } 11,61 \mathrm{ft} / \mathrm{s} \\
0,03+\mathrm{m} \cdot \mathrm{g}=0,03+(4 \cdot 9,8)\end{array}$ & $\begin{array}{l}\text { Kecepatan kepala saat mencapai lantai setelah } \\
\text { menempuh jaral A-C. } \\
\text { Besarnya gaya yang bekerja pada kepala pada saat }\end{array}$ \\
\hline Gaya (Fc) & $\tau+\mathrm{Fbc}$ & $=39,2 \mathrm{~N}$ & $\begin{array}{l}\text { mencapai lantai. Sesuai Hukum Newton III, maka kepala } \\
\text { juga akan mendapat gaya reaksi sebesar } 39,2 \mathrm{~N} \text {. }\end{array}$ \\
\hline Percepatan kepala di C & $\sum \mathrm{F}=\mathrm{Fb}+\mathrm{Fbc}$ & $\begin{array}{l}9,8 \mathrm{~m} / \mathrm{s} 2 \text { atau setara dengan } \\
1 \mathrm{G} \\
0,45+0,08=0,53 \mathrm{~s}\end{array}$ & $\begin{array}{l}\text { Percepatan kepala saat sampai di lantai setara dengan } \\
\text { gravitasi bumi. } \\
\text { Waktu yang dibutuhkan oleh kepala korban mulai dari }\end{array}$ \\
\hline Waktu total (dari A sampai C) & $T c=T b+T b c$ & $4 \times 3,54=14,2$ & $\begin{array}{l}\text { posisi awal sampai mengenai lantai kurang dari } 1 \text { menit. } \\
\text { Momentum total dari kepala mulai dari titik A ke titik } \mathrm{C} \text {. }\end{array}$ \\
\hline Momemtum Total & & $0,02+(4 \times 9,8 \times 0,24)=$ & Energi impak pada kepala adalah sebesar 9,42 J. \\
\hline Total Energi yang bekerja & $m h+m g h$ & $9,42 \mathrm{~J}$ & Total kekuatan yang diterima kepala per satuan waktu. \\
\hline Total Kekuatan Power $(P)$ & $\begin{array}{l}E D+m \cdot g \cdot n \\
P b+P b c\end{array}$ & $0,1+(39,2 \times 3,54)=138,8 \mathrm{~W}$ & Kecepatan rata-rata kepala saat menempuh jarak A \\
\hline Kecepatan rata-rata kepala $(A-C)$ & $v=\Delta s / \Delta T$ & $\begin{array}{l}(1,26+0,24) /(0,53)= \\
2,83 \mathrm{~m} / \mathrm{s}\end{array}$ & $\begin{array}{l}\text { sampai C (lantai). } \\
\text { Total kecepatan berubah terhadap waktu }\end{array}$ \\
\hline Percepatan rata-rata kepala $(A-C)$ & $\Delta$ Vrata-rata $/ \Delta \mathrm{t}$ & $\begin{array}{l}2,83 / 0,53=5,34 \mathrm{~m} / \mathrm{s}^{2} \text { atau } \\
0,5 \mathrm{G}\end{array}$ & \\
\hline
\end{tabular}




\section{Lampiran 2}

Tabel 2. Perhitungan indikator biomekanika trauma, dan simpulan dari perspektif forensik

\begin{tabular}{|c|c|c|}
\hline Indikator & Rumus & Parameter $(8,15)$ \\
\hline Maximum linear acceleration & $\mathrm{a}_{\max }$ atau a di $\mathrm{C}<\mathrm{N}$ & $\begin{array}{l}\text { probabilitas mTBI pada } \\
392,2 \mathrm{~m} / \mathrm{s}^{2} \text { adalah } 5 \%(8,15)\end{array}$ \\
\hline $\begin{array}{l}\text { Maximum linear acceleration } \\
\text { dihubungkan dengan waktu }\end{array}$ & $\begin{array}{c}\mathrm{a}_{\max }<400 \mathrm{G}, \text { atau } 200 \mathrm{G}<2 \mathrm{~ms} \text { dan } 150 \mathrm{G} \\
<4 \mathrm{~ms}\end{array}$ & $\begin{array}{l}\text { probabilitas mTBI pada } \\
\text { percepatan total kepala } \\
344,6 \text { adalah } 5 \%\end{array}$ \\
\hline Severity Index (SI) & $S I=\int_{T} a(t)^{2.5} d t$ & $\begin{array}{l}\text { Dibutuhkan angka } 1200 \mathrm{G} \\
\text { untuk mampu menimbulkan } \\
\text { mTBI. Penelitian } \\
\text { menunjukkan bahwa } \\
\text { probabilitas MTBI } 5 \% \text { akan } \\
\text { terjadi bila SI = 23,5G }\end{array}$ \\
\hline
\end{tabular}

The Head Injury Criterion (HIC)

Percepatan linear dan sudut GAMBIT

Rata-rata percepatan dengan lamanya waktu

$$
H I C=\left[\frac{1}{\left(t_{2}-t_{1}\right)} \int_{t_{1}}^{t_{2}} a(t) d t\right]^{2.5}\left(t_{2}-t_{1}\right)
$$

Angka standar untuk mampu menimbulkan MTBI adalah $1000 \mathrm{G}$. Probabilitas mTBI sebesar $50 \%$ akan terjadi pada $\mathrm{HIC}=239,8 \mathrm{G}$

Probabilitias terjadinya $\mathrm{mTB}$ pada GAMBIT 0,2231 adalah $5 \%$

$$
\left.G_{\text {max }}(t)=\left(\frac{a_{\text {res }}(t)}{250}\right)^{2}+\left(\frac{a_{\text {Its }}(t)}{25000}\right)^{2}\right]^{\frac{1}{2}}
$$

$$
\mathrm{a}^{-25} \mathrm{~T}<1,000
$$

$$
\begin{aligned}
H I P & =4.50 a_{x} \int a_{x} d t+4.50 a_{y} \int a_{y} d t \\
& +4.50 a_{z} \int a_{z} d t+0.018 \alpha_{x} \int \alpha_{x} d t \\
& +0.024 a_{y} \int u_{y} d t+0.022 u_{y} \int u_{y} d t
\end{aligned}
$$

TRISS (Trauma Injury Severity Score)
TRISS (blunt): Logit $=-0.4499+$ RTS*0.8085 + ISS*-0.0835 + (age.points) $*-1.7430$ Predicted death rate $=1 /\left(1+\mathrm{e}^{\text {Logit }}\right)$
Angka standar yaitu 1000 untuk mampu menimbulkan trauma

Probabilitas 5\% terjadinya mTBI adalah pada nilai HIP $4,7 \mathrm{~kW}$ atau $4700 \mathrm{~W}$

Penelitian di Malang melaporkan bahwa terdapat hubungan antara nilai Glasgow Coma Scale (GCS) saat datang dengan kematian, hampir setengah pasien $(45,5 \%)$ dengan GCS 5 8 dan $100 \%$ pasien dengan GCS $<5$ yang diintubasi dalam waktukurang dari 8 jam akan meninggal (16) pada korban ini percepatan akhir atau percepatan di $\mathrm{C}$ adalah sebesar $9,8 \mathrm{~m} / \mathrm{s}^{2}$, probabilitas terjadinya $\mathrm{mTB}$ I pada korban ini adalah sebesar kurang dari $5 \%$.

percepatan maksimal yang dialami oleh korban adalah sebesar 1,3G, probabilitas terjadinya mTBI pada korban sangat kecil $(<5 \%)$

SI pada korban ini adalah $=1 /(2,5+1) x$ $1^{2,5+1}+0,36=0,3+0,36=0,66 \mathrm{G}$. sehingga probabilitas timbulnya MTBI pada korban ini amat kecil $(<5 \%)$

$\mathrm{a}(\mathrm{t})=1 \mathrm{G}, \mathrm{t} 2-\mathrm{t} 1=36 \mathrm{~ms}(0,36)$ maka HIC adalah $\{1 / 0,36 \times(1 \times 0,36+0,36)$ \}$^{2,5} \times 0,36=(3,52)^{2,5} \times 0,36=0,6 \mathrm{G}$, sehingga probabilitas korban untuk mendapat $\mathrm{mTBI}$ adalah sebesar 239,8 / $50 \times 0,6=2,9 \%$.

$\mathrm{a}_{\text {res }}=$ percepatan linear total $=0,8 \mathrm{G}+$ $1 \mathrm{G}=1,8 \mathrm{G} ; \alpha_{\max }=1,3 \mathrm{G} ; \mathrm{t}=$ total waktu $=0,53 \mathrm{~s}$, maka angka $G_{\max }$ adalah sebesar $1 \times 10^{-5}$, angka GAMBIT yang terjadi oleh korban amat kecil, sehingga dapat disimpulkan bahwa probabilitas terjadinya mTBI kurang dari $5 \%$.

a rata-rata $=0,5 \mathrm{G}, \mathrm{T}=0,53$, maka di dapat angka sebesar 0,4 dan bila dilihat kurva Wayne State Tolerance Curve (WSTC) maka pada korban probabilitas terjadi fraktur pada tulang kepala adalah sangat kecil $(<1 \%)$

Dari perhitungan didapat HIP adalah sebesar 21,32W, jadi probabilitas terjadinya mTBI pada korban ini sangat kecil yaitu $0,02 \%$

Probabilitas mTBI sangat kecil, maka tidak akan mempengaruhi tekanan darah, frekuensi nafas dan tingkat kesadaran, sehingga nilai TRISS nya adalah : $0,3 \%$. 